九州大学学術情報リポジトリ

Kyushu University Institutional Repository

\title{
The Consistency of Consumer's Stated Preference and Revealed Preference : Evidence from Agricultural Product Market in China
}

Han, Qing

College of Economics and Management, China Agricultural University

Zhou, Hui

Institute of Agricultural Economics and Development, Chinese Academy of Agricultural Sciences : Laboratory of Agricultural and Farm Management, Division of International Agricultural Resource Economics and Business Administration, Department of Agricultural and Resource

Economics, Graduate School of Bioresource and Bioenvironmental Sciences, Kyushu University

Nanseki, Teruaki

Faculty of Agriculture, Kyushu University

Wang, Jimin

Institute of Agricultural Economics and Development, Chinese Academy of Agricultural Sciences

https://doi.org/10.5109/22076

出版情報: 九州大学大学院農学研究院紀要. 57 (1)，pp.227-234，2012-02. Faculty of Agriculture， Kyushu University

バージョン :

権利関係 : 


\title{
The Consistency of Consumer's Stated Preference and Revealed Preference: Evidence from Agricultural Product Market in China
}

\author{
Qing HAN ${ }^{1}$, Hui ZHOU ${ }^{2,3}$, Teruaki NANSEKI ${ }^{4}$ and Jimin WANG ${ }^{2 *}$ \\ Laboratory of Agricultural and Farm Management, Diversion of International Agricultural Resource Economics and \\ Business Administration, Department of Agricultural and Resource Economics, \\ Faculty of Agriculture, Kyushu University, Fukuoka 812-8581, Japan \\ (Received September 29, 2011 and accepted November 9, 2011)
}

\begin{abstract}
This paper analyzes the consistency of consumer's stated preference (SP) and revealed preference (RP) for fresh certified pork by using Beijing urban residents' questionnaire survey data in December 2010. It models the factors of the consistency of SP-RP and calculates the marginal effect coefficients. The results indicate that these factors of whether consumer's household have children under 18 years old, consumer's knowledge about certified products and searching frequency about food quality information have significant impacts on the consistent probability of SP-RP. Furthermore, the income limit and higher price of safe certified products are still the most important economic factors affecting consumers' consistency of SP-RP for safety certified pork.
\end{abstract}

\section{INTRODUCTION}

The remarkable economic changes since reform and opening-up in 1978 have resulted in Chinese consumers earning higher incomes and shifting consumption away from grains and legumes toward safe-quality livestock products. The increase of Chinese consumer income and the food safety issues lead to the demand surge of safequality agricultural products. The safe-quality agricultural products are rapidly developing with recent date indicating annual average growth rates of $15-20 \%$ in China. Forecasting the purchase intention of a new product, it needs to know the consumer's preference of agricultural product quality information. In some cases, researchers collect the data of consumer's stated preferences (known as SP) to predict his actual purchase behavior (known as Revealed Preference, RP) for safe food. Besides, the manufacturers make producing and marketing decisions based on these data in order to reduce market risks. However, the authenticity of stated preferences data was questioned by the economists who generally believed that there are significant differences between consumer's stated preferences described in the assumed experimental environment and his choice made in the real market (Loomis et al., 1996). One reason is that some tests are conducted in the circumstances that the consumers did not fully understand the specific characteristics of the new products, therefore, it would exist

1 College of Economics and Management, China Agricultural University, No 17 Tsinghuan East Road, Beijing, 100083, P. R. China

Institute of Agricultural Economics and Development, Chinese Academy of Agricultural Sciences, 12 Zhongguancun South Street, Beijing 100081, P. R. China

Laboratory of Agricultural and Farm Management, Division of International Agricultural Resource Economics and Business Administration, Department of Agricultural and Resource Economics, Graduate School of Bioresource and Bioenvironmental Sciences, Kyushu University, Japan

Faculty of Agriculture, Kyushu University, Japan

* Corresponding author (E-mail: wangjm@mail.caas.net.cn) a large deviation in the quality characteristics of the considered products between hypothetical and actual market circumstance. The second reason lies in that some products have public good characteristics such as zeroemission electric vehicles or natural gas vehicles. Consumers Sometimes will be inclined to choose such products based on the national strategies. However, in reality, the consumers do not want to pay the extra cost for cars with such features, especially in the case that their prices are much more expensive than the common ones. Although there are several limitations above, it is still widely used in the market researches. Some literatures analyzed correlation between SP-RP toward financial products and travel route selection (Loomis, 1993; Verhoef and Franses, 2003), and now few researches focus on the correlation between SP-RP in agricultural market.

Many studies have indicated that information asymmetry is one of the critical reasons that cause food safety issues and affect consumer's food choice (Mccluskey et $a l ., 2000$; Feddersen and Gilligan, 2001). The agricultural market is a lemons market typically in which emerges market failure during the information transmission and drives the safe-quality food out of the market or resulting in an inefficient allocation. The quality guarantee from the third party and food traceability networks are examples of systems used to help bridge the information gap between market players and reduce inefficiencies that arise from asymmetric information (Piggott and Marsh, 2004; Ortega et al., 2011). However, consumer's preference and confidence about safe-quality food have steadily dropped with the outbreak of a series of food safety scares, such as mad cow disease scandals and melamine contamination in milk powder. There is a clear link between the mad cow disease scandals and the beef consumption decrease sharply (Wallace et al., 2005). In some cases, consumer's actual purchase behavior will be different from his stated preference for safe-quality food. Deeper understanding the consistency of SP-RP will take an important effect in the supply and policy-making 
of safe-quality agricultural products.

This paper discusses the affecting factors of consistency of consumer's SP-RP for safe-quality food and influence degree by using Binary Logistic model. The paper is organized as follows: Section 2 introduces a framework and specification for empirical model. Section 3 provides the descriptive statistics of collected date. Section 4 gives the regression results and discussion, and finally summaries the conclusions and suggestions.

\section{A FRAMEWORK AND SPECIFICATION FOR EMPIRICAL MODEL}

\section{A theore tical frame work}

Pork has historically been the primary animal protein source in Chinese diets, and its consumption amount has more than tripled between 1980 and 2008. Safecertification pork products are popularized in large and medium-sized retail markets. Taking the fresh certified pork as example, the paper analyzes the consumer's stated preference and revealed preference. We design some characters of fresh pork such as price, certified marks, manufacture date, the convenience and health of sale place, nutrition and taste, and inquire the respondent which characters is his primary consideration when taking his purchase decision. If the respondent takes certified marks as his primary purchase basis, we consider the consumer has stated preference for certified fresh pork. Unlike other home appliances, agricultural products are of higher purchase frequency. Previous studies analyzed consumer's once purchase behavior for certified agricultural products in experiment or real market, which cannot reflected his stable purchase preference. Considered above reason, we investigate respondent's purchase cases about fresh pork including certified pork and ordinary pork in recent one month, and his recall of certified fresh pork purchase behavior in the year of 2010, and then assess the consumer's certified pork purchase proportion. We assume that if the consumer daily purchase proportion for certified pork more than half of total fresh pork, and he will have purchase preference for fresh certified pork. If consumer has stated preference and his purchase rate for fresh certified pork exceeds 50\% in his daily life, then his SP-RP is consistent. Otherwise, although consumer has stated preference, the purchase rate is less than 50\%, and his SP-RP is inconsistent.

Consumer's purchase decision is a complicated and rational process which aims to the maximization of utility. The outbreak of food safety problems will induce consumer's concerns about the safe-quality because the market failure caused by asymmetric information between sellers and buyers in imperfect market. Consumer's concern about food safety issue leads to increased demand for wholesome foods. With the increase of food safety risks, consumers tend to be aware of and involved with nutrition, and adopt a healthy eating habit (Kraft and Goodell, 1993). In addition, they have preference for buying high quality, nutritious, healthy foods which help enhance wellbeing and avoiding foods with additives or preservatives (Harper and Makatouni, 2002). Consumers having more perception about food safety risks will tend to consistent with their SP-RP for healthful food.

Quality certification is an important signal for the manufacturers to transmit quality information to consumers smoothly. Some researches show the consumers have more knowledge about quality information, the much more possibility they would have purchase intention toward these products. Briz and Ward (2009) studied the Spanish consumption behaviors of organic food, and found that with the rising of consumer cognition about organic food, the consumption ratio of organic food had been greatly increased. Kim et al. (2001) showed that regardless of the type of nutrition information provided, label use would improve the overall quality of consumer diets. In order to get knowledge about whether qualities of agricultural products were safe, consumers needed to spend time and efforts. The consumers bought such products that they familiar with could reduce the search costs on product quality, and it was a more economical choice (Yi and La, 2004). Consumers grasping much more knowledge about certified products, their consistency of SP-RP will be higher.

Azevedo et al. (2003) found that, compared to their answers about SP questions, consumers made actual purchase decisions often considered their budgets, and price orientation played an important role in purchase decisions in real market. Compared with ordinary agricultural products, the price of safe-quality food is generally higher. All other conditions being equal, the stronger the consumers' purchase intention and willingness level to pay for safe agricultural products, the lower probability of difference of SP-RP will be (Loureiro et al., 2003).

After consuming the product, consumer will compare its actual quality with his expectation by which accumulating experience for later purchase behavior. The higher level trust toward safe-quality products, the consumer has much more inclination to purchase these products in later purchase choice. Some research shows that there is a positive and significant effect between acceptance for gene technology and purchase behavior (Rosati and Saba, 2000). Thus, the high-level trust consumers had in certified products, the much more consistent of SP-RP.

Socio-demographic variables also affect consumer's attitude and purchase intention to the safe food in some literatures. Wandel and Bugge (1997) found that older consumers are more concerned about healthiness when buying organic produce compared to younger consumers. Thompson (1998) found positive correlation between education and organic purchases behavior. The consumers' income positively correlated to their household consumption number and quality, which mainly because higher income could lead to stronger purchase ability (Bowman and Gortmaker, 2004). Consumers of higher income would have more option and endurance for high quality and high price products, thus, they will have larger possibility of the consistency of SP-RP.

Using these findings, the proposed conceptual model is graphically presented in Fig. 1. 


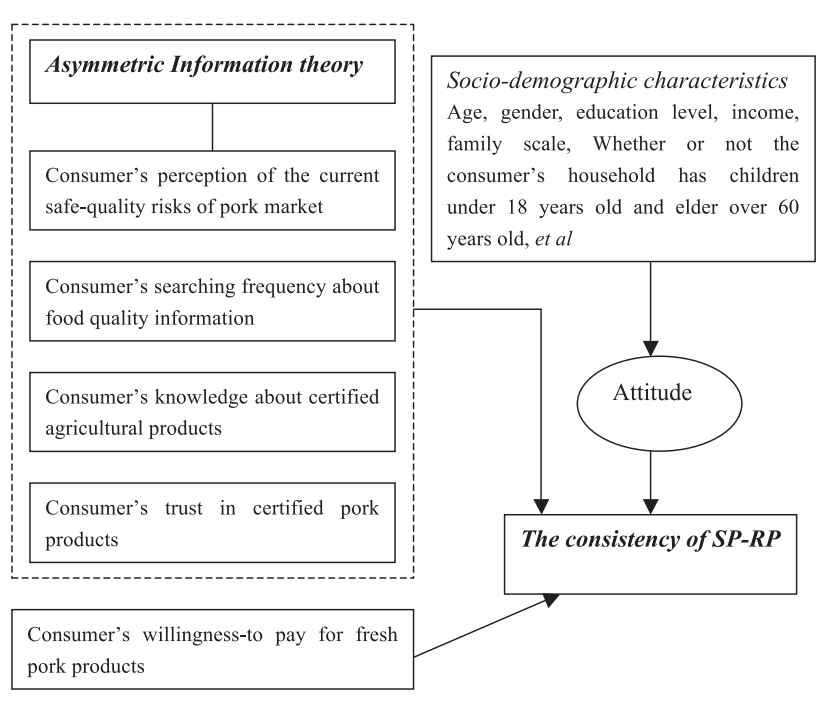

Fig. 1. Conceptual framework.

\section{Specification for empirical model}

The paper summaries 12 factors influencing consumers' consistency of SP and RP for certified pork products according to Fig. 1.

We set up the following equation:

$$
y_{i}=\beta_{0}+\beta_{1} x_{1}+\beta_{2} x_{2}+\cdots \cdots \beta_{12} x_{12}
$$

In Equation (1), $y_{i}$ is the probability that the $i$-th consumer has consistent $\mathrm{SP}$ and RP.

$y_{i}$ is valued o if the consumer's $\mathrm{SP}$ and $\mathrm{RP}$ is different; $y_{i}$ is valued 1 if the consumer's $\mathrm{SP}$ and RP is consistent. $x_{1}, x_{2}, \cdots \cdots, x_{12}$ represent explanatory variables. The paper uses binary logistic model to do the regression analysis. And the model form is:

$$
p_{i}=F\left(\alpha+\sum_{j=1}^{12} \beta_{j i} x_{j}\right)=1 /\left\{1+\exp \left[-\left(\alpha+\sum_{j=1}^{12} \beta_{j} x_{j}\right)\right]\right\}
$$

Rewrite the Equation (2) as:

$$
\text { In }\left(\frac{p_{i}}{1-p_{i}}\right)=\alpha+\sum_{j=1}^{12} \beta_{j} x_{j}
$$

In equation (3), $p_{i}$ represents the probability of the ith consumer has consistent SP and RP for certified fresh pork.

In order to take further study about the effects when explanatory variables change taken on consumer's SP-RP consistency probability, the paper established the marginal effects formula as follows:

$$
\frac{\partial p}{\partial x_{k}}=\beta_{k} \frac{\exp \left(x_{i} \beta\right)}{\left[1+\exp \left(x_{i} \beta\right)\right]^{2}}=\beta_{k} \Lambda\left(x_{i} \beta\right)\left[1-\Lambda\left(x_{i} \beta\right)\right]
$$

Another complication for computing marginal effects in a binary choice model arises because $\mathrm{x}$ will often include dummy variables. In this binary logistic model, $\mathrm{x}$ contains such dummy variables as consumers' marital status, whether the household has children under 18 years old, or has old person over 60 years old. According to the Greene (2007), the appropriate marginal effect for a binary independent variable, say d, would be as follows:

$$
\operatorname{Prob}\left[Y=1 / \bar{x}_{(d)}, d=1\right]-\operatorname{Prob}\left[Y=1 / \bar{x}_{(d)}, d=0\right]
$$

Where $\bar{x}_{(d)}$ denote the means of all the other variables in the model.

\section{DATASET AND DESCRIPTIVE STATISTICS}

\section{Dataset}

Data were gathered from consumer questionnaire surveys in December 2010. Combining with economic development level, population characteristics, distribution of major shopping malls and supermarkets in Beijing, we selected typical survey districts in which chose 2-3 supermarkets (such as Carrefour, Chaoshifa, Lotus Supercenter, et al.), shopping malls, residential squares and agricultural products retail market. Our respondents are main buyers of food for the household. The survey totally gathered 614 samples.

Table 1 provides details of the sample characteristics. The samples comprise $74.3 \%$ females and $85.9 \%$ married respondents. The ages of the samples mainly distribute among $21 \sim 40$ accounting for $57.7 \%$ of totals. The education levels are mainly concentrated on high school and university degree. $50.7 \%$ respondents' monthly household income varies between 4001 and 6000 RMB. The average family scale of the samples is 3.2. The samples are mainly occupied in enterprises, which take up $44.9 \%$ of totals. The samples are comparable to Beijing Census by Beijing Statistics Bureau 2010 in terms of age, monthly household income, occupation and family scale. However, the samples' educational level is higher than the average level of the Beijing Census statistics which is features common to many other surveys.

There are 342 samples taking safety certification marks as the first basis of purchasing decisions and having stated preference for certified pork which account for $55.7 \%$ of total samples. Only 95 consumers have the consistency of SP and RP for certified pork in their daily life and take up $15.5 \%$ of the totals. There are 247 consumers have inconsistent probability of SP and RP for certified pork products. The survey shows that there is a big difference between urban residents' SP-RP for safe certified pork products in Beijing currently (See Table 2). The paper empirically analyzes the factors of consumer's SP-RP using those 342 samples that have sated preference for certified pork products.

\section{Variables explanation}

This study has 12 explanatory variables, of which the descriptive statistics analysis is shown in Table 3. The interpretations for some of the explanatory variables are given.

(1) Consumer's knowledge of certified agricultural product's quality and safety information. There are three kinds of certified marks designed in the questionnaire: green food, free-pollution food and organic food. We design four aspects questions such as certified product symbols, certification procedures, quality control proc- 
Table 1. Socio-demographic characteristics of respondents

\begin{tabular}{lclc}
\hline \multicolumn{1}{c}{ characteristic } & percentage & characteristic & \\
\hline Gender & & Marital status & 14.1 \\
male & 25.7 & Unmarried & 85.9 \\
female & 74.3 & Married & 11.3 \\
\hline Age & & Education level & 36.0 \\
\hline 21-30years old & 20.9 & Junior middle school and below & 10.0 \\
31-40 years old & 36.8 & High school & 39.1 \\
41-50 years old & 16.2 & Junior College & 3.6 \\
51-60 years old & 12.8 & Undergraduate & 25.6 \\
Over 60 years old & 13.3 & Master and above & 44.9 \\
Monthly household income & & Occupation & 29.5 \\
\hline 2000RMB and below & 1.6 & Administrative and public institutions \\
2001 4000RMB & 14.6 & Enterprises & \\
4001 6000RMB & 50.7 & The others & \\
6001 9000RMB & 10.1 & & \\
9001 12000RMB & 12.6 & & \\
12001 16000RMB & 5.7 & & \\
16001 20000RMB & 2.9 & & \\
Over 20000RMB & 1.6 & & \\
\hline
\end{tabular}

Notes: $1 \mathrm{RMB}=0.1538 \$$

Source: self calculation based on field survey 2010

Table 2. The overview of consumer's SP and RP (person)

\begin{tabular}{lccc}
\hline & Consumers having RP & Consumers not having RP & Total \\
Consumers having SP & 95 & 247 & 342 \\
Consumers not having SP & 28 & 244 & 272 \\
Total & 123 & 491 & 614 \\
\hline
\end{tabular}

Source: self calculation based on field survey 2010

esses and inspection standards, let consumers answer these questions in order to investigate consumer's understanding about three certified products.

(2) The consumer's trust in the quality of certified pork products. This paper designed "Do you believe that the pork with quality-certified marks is strictly produced in accordance with the certification standards?", and consumers could choose from five options, such as "totally distrust, slightly distrust, do not know, slightly trust, and completely trust" which respectively valued 1-5 according to Likert-type scale. The higher value indicates that consumers have higher trust level in certified pork products.

(3) Consumer's willingness-to-pay for certified pork products. Based on the market survey in the typical supermarkets and shopping malls in Beijing, we evaluated the prices of three kinds of certified pork products, respectively as $36 \mathrm{RMB} / \mathrm{kg}, 50 \mathrm{RMB} / \mathrm{kg}$ and $64 \mathrm{RMB} / \mathrm{kg}$. If the respondents think the certified pork price is too high, then continue to investigate their willingness-to-pay for this kind of certified pork product. If the price of certified pork is within the scope of their ability to pay, then their willingness-to-pay would be current estimated price. The average payment for three kinds of certified pork is their willingness-to-pay for the certified pork products.

\section{Descriptive statistics of consumer's safe purchase behaviors}

The willingness-to-pay for certified pork products and their respective ratio to present market price are given in Table 4. The ratio of willingness-to-pay to present market price for three certified pork products (free-pollution food, green food, and organic food) are 87.9\%, 80.0\% and $75.3 \%$ respectively. The difference between consumers' willingness-to-pay for the organics and its relative market price is larger than the other certified products. Compared with consumers who having inconsistency of SP and RP, consumers having consistency of SP and RP have higher willingness-to-pay for certified pork products.

Regarding to the consumer's knowledge about certified agricultural products, there are $12.2 \%$ samples among 41 respondents with low-level knowledge about certified products (the number of their correct answer is less than 6), and 34.9\% samples among 132 respondents with 
Table 3. Assignment and descriptive statistics of the explanatory variables

\begin{tabular}{|c|c|c|c|}
\hline Explanatory variables & Variables assignment & Mean & $\mathrm{SD}$ \\
\hline Gender & $0=$ female; $1=$ male & 0.06 & 0.23 \\
\hline Age & $21-30=1,31-40=2,41-50=3,51-60=4$, over $60=5$ & 2.65 & 1.44 \\
\hline Educational level & $\begin{array}{l}\text { Junior middle school and below }=1 \text {, High school }=2 \text {, Junior } \\
\text { College }=3 \text {, Undergraduate }=4 \text {, Master degree and above }=5\end{array}$ & 2.94 & 1.12 \\
\hline Monthly household income & $\begin{array}{l}2000 \mathrm{RMB} \text { and below }=1,2001-4000 \mathrm{RMB}=2,4001-6000 \mathrm{RMB}=3 \text {, } \\
6001-9000 \mathrm{RMB}=4,9001-12000 \mathrm{RMB}=5,12001-16000 \mathrm{RMB}=6 \text {, } \\
16001-20000 \mathrm{RMB}=7 \text {, over } 20000 \mathrm{RMB}=8\end{array}$ & 3.85 & 1.39 \\
\hline Family scale & According to the actual population in family & 3.25 & 1.16 \\
\hline $\begin{array}{l}\text { Whether consumer's household has children } \\
\text { under the age of } 18\end{array}$ & $0=$ no; $1=$ yes & 0.88 & 0.33 \\
\hline $\begin{array}{l}\text { Whether consumer's household has the elder } \\
\text { over } 60 \text { years old }\end{array}$ & $0=$ no; $1=$ yes & 0.42 & 0.49 \\
\hline $\begin{array}{l}\text { Consumer's searching frequency about food } \\
\text { quality information }\end{array}$ & $\begin{array}{l}\text { Totally not searching }=1 \text {, not searching }=2 \text {, uncertain }=3 \text {, more } \\
\text { searching }=4 \text {, most searching }=5\end{array}$ & 1.96 & 0.58 \\
\hline $\begin{array}{l}\text { Consumer's perception of the current safe-- } \\
\text { quality risks of pork market }\end{array}$ & $\begin{array}{l}\text { There is no safety risks }=1 \text {, there is less safety risks }=2 \text {, uncertain }=3 \text {, } \\
\text { there are more safety risks }=4 \text {, there is a strong safety risks }=5\end{array}$ & 3.82 & 0.60 \\
\hline $\begin{array}{l}\text { Consumer's knowledge about certified } \\
\text { agricultural products }\end{array}$ & Based on the number of correct answer for these questions & 8.58 & 1.77 \\
\hline $\begin{array}{l}\text { Consumer's willingness-to-pay for certified } \\
\text { pork products }\end{array}$ & The average willingness to pay of three kind of the certified pork & 19.98 & 2.06 \\
\hline $\begin{array}{l}\text { Consumer's trust in the quality of certified } \\
\text { pork products }\end{array}$ & $\begin{array}{l}\text { Totally distrust }=1 \text {, slightly distrust }=2 \text {, do not know=3, slightly } \\
\text { trust }=4 \text {, completely trust }=5\end{array}$ & 2.21 & 0.61 \\
\hline
\end{tabular}

Source: self calculation based on field survey 2010

Table 4. The correlation of consumer's willingness-to-pay and consistency of SP and RP

\begin{tabular}{|c|c|c|c|c|c|c|}
\hline & \multicolumn{2}{|c|}{ Total samples } & \multicolumn{2}{|c|}{$\begin{array}{l}\text { Consumers having } \\
\text { inconsistency of SP and RP }\end{array}$} & \multicolumn{2}{|c|}{$\begin{array}{c}\text { Consumers having } \\
\text { consistency of SP and RP }\end{array}$} \\
\hline & WTP (RMB/kg) & Percentage & WTP (RMB/kg) & Percentage & WTP (RMB/kg) & Percentage \\
\hline free-pollution food & 31.6 & 87.9 & 30.6 & 84.9 & 34.5 & 95.7 \\
\hline green food & 40.0 & 80.0 & 38.5 & 77.1 & 43.9 & 87.7 \\
\hline organic food & 48.2 & 75.3 & 46.1 & 72.0 & 53.7 & 84.0 \\
\hline
\end{tabular}

Source: self calculation based on field survey 2010

Table 5. Consumer's knowledge about certified agricultural products

\begin{tabular}{|c|c|c|c|c|c|}
\hline \multirow{2}{*}{ The level } & \multicolumn{2}{|c|}{ The inconsistency of SP-RP } & \multicolumn{2}{|c|}{ The consistency of SP-RP } & \multirow{2}{*}{ Sample size } \\
\hline & frequency & percentage & frequency & percentage & \\
\hline low & 36 & 87.8 & 5 & 12.2 & 41 \\
\hline moderate & 125 & 74.0 & 44 & 26.0 & 169 \\
\hline high & 86 & 65.1 & 46 & 34.9 & 132 \\
\hline Total & 247 & 72.2 & 95 & 27.8 & 342 \\
\hline
\end{tabular}

Source: self calculation based on field survey 2010

high-level knowledge (consumers can answer more than 10 questions correctly) having consistent SP-RP. From the view of the group having consistent SP-RP, with the improvement of knowledge, the consumer has much more probability of consistency of SP-RP (See Table 5).

As to consumer's trust level of the quality of certified pork products, only a handful of respondents completely believe that the pork with quality-certified marks is strictly produced in accordance with the certification standards. More than 80\% respondents have suspicious attitude about the quality of certified pork products (See Fig. 2). The results indicate that frequent food safety accidents in China cripple the consumer's confidence in safe-quality of pork products and in turn restrict his purchase intention for those healthy foods. 


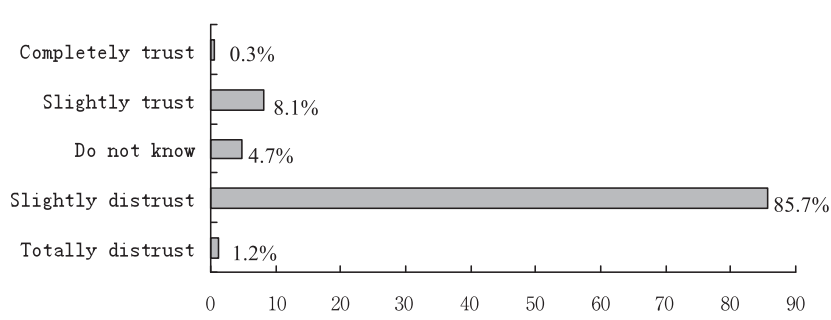

Fig. 2. Consumer's trust in the quality of certified pork products. Source: self calculation based on field survey 2010 .

\section{EMPIRICAL ESTIMATION RESULTS AND DISCUSSION}

We firstly take $\mathrm{z}$-score normalization about the different nature of explanatory variables except dummy variables such as gender, whether consumer's household have children under 18 years old and the elder over 60 years old before regressing. The purpose of normalization is to resolve the comparability of parameters. This study uses binary logistic model to do the regression and Model I is the regression result directly and Model II is the regression result after normalization (See Table 6). According to Equation (4) and (5), Marginal effects coefficients of significant explanatory variables in Model I and Model II are shown in Table 7.

The regression results indicate that consumer's individual characteristics such as gender, age and education level have not a significant effect on the consistency of $\mathrm{SP}-\mathrm{RP}$ for certified pork products.

The findings show that consumer's monthly household income and willingness- to-pay for certified pork have positive effect on the consistency of SP-RP at a significant level of 1\%. Household income is a variable reflecting consumer's payment ability; consumers with higher income have much more consistency of SP-RP.
According to the survey, it is found that compare with ordinary pork, the price of current certified pork are generally higher than respondents expected. The price of the same part of certified fresh pork is about 60\% higher than the ordinary in Beijing. Furthermore, the price of organic pork is almost twice as much as those of the ordinaries and far exceeds the acceptable of lowincome consumers. Both consumers' income and payment have direct impacts on their purchase behavior of certified products. The probability of SP-RP consistency will increase $9.27 \%$ if consumers' monthly household income increases one unit. Consumers' willingness-topay increase one unit and it will raise $10.99 \% \mathrm{SP}-\mathrm{RP}$ consistent probabilities respectively (see Table 7).

Compare with families without children under 18 years old, consumers whose household with children has higher consistent probability of SP-RP for certified products at $10 \%$ significance level. Compared with families without children, consumers having children will increase $14.17 \%$ of the probability of the SP-RP consistency (see Table 7).

There is a positive interrelation between consumer's searching frequency about food quality information and his $\mathrm{SP}-\mathrm{RP}$ of certified pork products at significant level of $10 \%$. The increase of searching frequency will affect consumer's attitude and acceptance of credence goods, such alleviates asymmetric information between production and consumption link in imperfect market. The result in Table 7 shows that consumer's searching frequency about quality information increases one unit, consumer's consistent probability of SP-RP will raise $8.31 \%$ correspondingly.

Consumer's knowledge about certified agricultural products affects positively the consistency of SP-RP at the significant level of $10 \%$. Consumer could make rational purchase choice only by the ways of learning

Table 6. Binary logistic model regression results

\begin{tabular}{lcc}
\hline Parameters & Model I & Model II \\
\hline Gender & -0.493 & -0.493 \\
Age & 0.058 & 0.084 \\
Education level & 0.273 & 0.306 \\
Monthly household income & $0.765^{* * *}$ & $1.067^{* * *}$ \\
Family scale & 0.275 & 0.318 \\
Whether consumer's household have children under 18 years old & $1.169^{*}$ & $1.169^{*}$ \\
Whether consumer's household have the elder over 60 years old & -0.191 & -0.191 \\
Consumer's searching frequency about food quality information & $0.685^{*}$ & $0.401^{*}$ \\
Consumer's perception of the current safe-quality risks of pork market & 0.641 & 0.382 \\
Consumer's knowledge about certified agricultural products & $0.245^{*}$ & $0.433^{*}$ \\
Consumer's willingness-to-pay for certified pork products & $0.907^{* * *}$ & $1.871^{* * *}$ \\
Consumer's trust in the quality of certified pork products & 0.347 & 0.211 \\
$\chi^{2}$ & 0.459 & 0.459 \\
-2 Log likelihood & 194.223 & 194.223 \\
Nagelkerke R ${ }^{2}$ & 0.662 & 0.662 \\
\hline
\end{tabular}

Note: ***,**,* respectively represents statistical significance in $0.01,0.05,0.10$ level.

Source: self calculation based on field survey 2010 
Table 7. Marginal effect coefficients (\%)

\begin{tabular}{lllll}
\hline $\begin{array}{l}\text { Explanatory } \\
\text { variables }\end{array}$ & $\begin{array}{l}\text { Monthly household } \\
\text { income }\end{array}$ & $\begin{array}{l}\text { Whether consumer's } \\
\text { household have } \\
\text { children under 18 years } \\
\text { old }\end{array}$ & $\begin{array}{l}\text { Consumer's searching } \\
\text { frequency about food } \\
\text { quality information }\end{array}$ & $\begin{array}{l}\text { Consumer's } \\
\text { knowledge about } \\
\text { certified agricultural } \\
\text { products }\end{array}$ \\
\hline Model I & 9.27 & 14.17 & 8.31 & $\begin{array}{l}\text { Consumer's } \\
\text { willingness-to-pay for } \\
\text { products }\end{array}$ \\
\hline Model II & 12.93 & 14.17 & 4.86 & 5.25 \\
\hline
\end{tabular}

Source: self calculation based on regression results

much knowledge about certified agricultural products in imperfect market. Consumer's accurate judgments about production standards of certified agricultural products would reduce the degree of information asymmetry and raise his purchase preference of these healthy foods. Consumer's knowledge about certified agricultural product increases one unit, his consistent probability of SP-RP will raise $2.97 \%$ (Table 7 ).

The two factors of consumer's perception about the current safe-quality risks of pork market and trust in the quality of certified pork products have no significant effects on the consistency of SP-RP. A series of food safety issues arouse the consumer's inclination about healthy food and make his potential motivation to actual purchase behavior, but consumers can not change the potential preference into real purchase behaviors because of some economic limitation.

Marginal effect coefficients in Model II can reflect the real impacts of consistent probability of SP and RP when explanatory variables change without the limitation of dimension. It is showed that the economic factors of consumer's household income and willingness-to-pay have the largest impacts on his consistency of SP an RP, and followed by the variable of whether consumer's household have children under 18 years old and the lack of knowledge caused by asymmetric information.

\section{CONCLUSIONS AND SUGGESTIONS}

This paper examined urban consumer's stated preference and revealed preference for safety certified fresh pork in Beijing, and then conducted an empirical study on factors affecting consumer's SP-RP consistency and the effect degree. It is found that despite more than 50\% of the consumers have stated preference for certified pork products, but only $15.5 \%$ of the consumers have the consistency of SP and RP for certified pork in their daily life. The number of urban residents who have stable purchase preference for certified pork in Beijing currently is smaller compared with those in developed countries. There is a big difference between consumer's stated preference and revealed preference for certified pork products. The food safety accidents in China reduce the consumer's trust in safe-quality and restrict his purchase intention. The constraints of consistency of SP and $\mathrm{RP}$ are income, higher-price of certified products and the lack of knowledge caused by asymmetric information currently in Beijing.

Compared with developed countries, the realities of small-scale farmer production, lack of severe regulations and imperfect supervised systems in China restrict consumer's trust in the food safe-quality and inclination for healthy food. The government should improve legislations and establish a strict food traceability system from farmer to consumer in order to control producing and marketing behaviors in agricultural market. The knowledge publicity such as consumer-training program, quality authentication conference presided by experts and technicians, products advertisements and promotion will ease the asymmetric information and enhance the consistency of SP-RP for safe food.

The finding in this study indicates the important factors of income and price bind restrict safety consumption. Support policy in livestock industry should be taken into consideration in China. Declining the costs in the link of production, circulation and marketing will cut down the final price of certified pork products and enhance consumer's the acceptable for safe food.

The survey results about consumer's purchase intention may be inclined to exaggerate consumer's actual purchasing ability for safe food. Therefore, the marketers should not be blindly optimistic to survey results of consumer's demand for certified agricultural products. Those who have higher income, cognition and willingness-to-pay for certified agricultural products will have higher probability of real purchase preference.

\section{ACKNOWLEDGEMENTS}

This research is based upon work supported by the Beijing Philosophy and Social Science Foundation under Grant No. 10BaJG325 and special fund from the modern industrial technology system innovation of Beijing industrial economy research team.

\section{REFERENCES}

Azevedo, C. D. Herriges, J. A. and Kling, C. L. 2003 Combining Revealed and stated Preference: Consistency Tests and Their Interpretations, American Agricultural Economics Association, 85(3): 525-537

Bowman, S. A. and Gortmaker, C. B. 2004 Effects of Fast-food Consumption on Energy Intake and Diet Quality among Children in a National Household Survey, Pediatrics, 113(1): $112-118$

Briz, T. and Ward, R. W. 2009 Consumer awareness of organic products in Spain: An application of multinominal logit models, Food Policy, 34: 295-304

Feddersen, T. J. and Gilligan, T. W. 2001 Saints and markets: activists and the supply of credence goods, Journal of 
Economics and Management Strategy, 10(1): 149-171

Harper, G. C. and Makatouni, A. 2002 Consumer perception of organic produce production and farm animal welfare, British Food Journal, 104(5): 287-299

Kim, S. Y. Nayga, R. and Capps, O. 2001 Food label use, selfselectivity and diet quality, The Journal of Consumer Affairs, 35(2): 346-363

Kraft, F. B. and Goodell, P. W. 1993 Identifying the health conscious consumer, Journal of Health Care Marketing, 13(3): $18-25$

Loomis, J. T. 1993 An Investigation into the Reliability of Intended Visitation Behavior, Environmental and Resource Economics, 3(2): 183-191

Loomis, J. T. Brown, B. and George, P. 1996 Improving Validity Experiments of Contingent Valuation Methods: Results of Efforts to Reduce the Disparity of Hypothetical and Actual Willingness to Pay, Land Economics, 72(9): 450-461

Loureiro, M. L McCluskey, J. J. and Mottelhammer, R. C 2003 Are Stated Preferences Good Predictors of Market Behavior? Land Economics, 82(4): 623-640

Mccluskey, J. J. 2000 A game theoretic approach to organic foods: an analysis of asymmetric information and policy, Agricultural and Resource Economics Review, 29: 1-9
Ortega, D. L, Wang, H. Wu, L. P. and Olynk, N. J. 2011 Modeling heterogeneity in consumer preferences for select food safety attributes in China, Food Policy, 36: 318-24.

Piggott, N. E. and Marsh, T. L. 2004 Does food safety information impact U.S. meat demand, American Journal of Agricultural Economics, 86(1): 154-174

Rosati, S. Saba, A. 2000 Factors influencing the acceptance of food biotechnology, Italian Journal of Food Science, 12(4) 425-434

Thompson, G. D. 1998 Consumer demand for organic food: what we know and what we need to know, American Journal of Agricultural Economics, 80 (5): 1113-1118

Verhoef, P. C. and Franses, P. H. 2003 Combining Revealed and stated Preferences to Forecast Customer Behavior: Three Case Studies, International Joumal of Market Research, 45(4): 467-474

Wallace, M. S. Y. Ruth, M. W. Y. and Joe, M. 2005 Food safety: building consumer trust in livestock farmers for potential purchase behaviour, British Food Journal, 107(11): 841-854

Yi Y. and La S. 2004 What Influences the Relationship Between Customer Satisfaction and Repurchase Intention? Investigation the Effect of Adjusted Expectations and Customer Loyalty, Psychology \& Marketing, 21(5): 351-373 